chúng tôi quan sát sự thay đổi số lượng và hình thái của tế bào Hep2 điều trị bằng $\mathrm{MeV}$ và Nimotuzumab trên đĩa nuôi cấy bằng kính hiển vi thường. Điều này cho thấy: Quá trình apoptosis sớm diễn ra ở các nhóm điều trị bằng $\mathrm{MeV}$ rõ rêt từ thời điểm 48 giờ, tới thời điểm 72 giờ thì quá trình apoptosis sớm giảm, quá trình apoptosis muộn tăng lên, tới thời điểm 96 giờ thì quá trình hoại tử tế bào tăng lên rõ rêt. Quá trình apoptosis diễn ra ở nhóm điều trị bằng Nimotuzumab diễn ra chậm hơn so với nhóm MeV: tại thời điểm 48 giờ tỷ lê tế bào apoptosis ít, tại thời điểm 72 giờ tỷ lệ tế bào apoptosis sớm và muộn tăng rõ, tại thời điểm 96 giờ thì tỷ lệ apoptosis sớm đạt mức cao nhất và cao hơn nhóm điều trị bằng MeV.

$\mathrm{MeV}$ chủng Edmonston sử dung thu cảm thể đặc hiệu CD46 để xâm nhập vào tế bào đích. CD46 không chỉ là nơi MeV gắn và xâm nhập vào tế bào, mà còn thúc đẩy quá trình virus tạo ra sự hợp bào giữa tế bào bi nhiếm virus và các tế bào ung thư lân cận 4. Như vậy, ở các tế bào bình thường có mật độ CD46 thấp, MeV có khả năng lây nhiễm tạo hợp bào là không đáng kể và không có khả năng phát tán virus. Ở các tế bào ung thư có biểu hiện thụ thể CD46 cao, lây nhiễm $\mathrm{MeV}$ dẫn đến phản ứng hợp bào mạnh mẽ. Nghiên cứu gần đây trên 38 bệnh nhân đa u tủy thì mức độ biểu hiện CD46 ở các tế bào u tủy cao hơn nhiêu (49.130/tế bào) so với các tế bào tủy xương bình thường (7.340/tế bào). Hiệu quả phá hủy tế bào manh mẽ của sự hợp bào trên phạm vi rộng lớn đã được quan sát thấy trong các tế bào u tủy sau khi điêu trị bằng virus sởi, hầu như không xảy ra ở các tế bào tủy xương bình thường 5 .

\section{KẾT LUÂN}

Nghiên cứu của chúng tôi cho thây khả năng gây tăng khả năng chết theo chương trình giai đoạn muộn trên tế bào ung thư đầu cổ của virus vaccine sởi và Nimotuzumab in vitro. Việc kết hợp MeV và Nimotuzumab gây chết theo chương trình giai đoạn muộn làm tăng có ý nghĩa thống kê số lượng tế bào chết apoptosis muộn so với điều trị đơn MeV hoặc Nimotuzumab trên dòng tế bào Hep2.

\section{TÀl LIỆ THAM KHẢO}

1. Vigneswaran N., Williams M.D. (2014). Epidemiologic trends in head and neck cancer and aids in diagnosis. Oral Maxillofac Surg Clin North Am., 26(2):123-141.

2. Prestwich R.J., Harrington K.J., Pandha H.S., et al. (2008). Oncolytic viruses: a novel form of immunotherapy. Expert Rev Anticancer Ther., 8(10):1581-1588.

3. Miyamoto $S_{.,}$Inoue $H_{.}$, Nakamura $T_{\text {., }}$ et al. (2012). Coxsackievirus B3 is an oncolytic virus with immunostimulatory properties that is active against lung adenocarcinoma. Cancer Res., 72(10): 2609-2621.

4. Msaouel P., Opyrchal M., Domingo Musibay E., et al. (2013). Oncolytic measles virus strains as novel anticancer agents. Expert Opin Biol Ther., 13(4):483-502.

5. Ong H.T., Timm M.M., Greipp P.R., et al. (2006). Oncolytic measles virus targets high CD46 expression on multiple myeloma cells. Exp Hematol., 34(6):713-720.

\title{
NGHIÊN CỨU MỐI LIÊN QUAN GIỮA LÂM SÀNG VÀ HÌNH ẢNH CLVT Sọ NÃO ở BÊ̂NH NHÂN ĐộT QUỴ NÃO CẤP
}

\section{TÓM TẮT}

Muc tiêu: Nghiên cứu mối liên quan giữa lâm sàng và hình ảnh CLVT sọ não ở bệnh nhân đột quy. não cấp. Đối tượng và phương pháp: NC tiến cứu, mô tả cắt ngang 120 bệnh nhân được chẩn đoán lâm sàng là đột quy não cấp và được chụp chụp CLVT sọ não không tiêm thuốc cản quang tại Bệnh viện ĐKKV

\footnotetext{
*Trương $Đ H$ Y khoa Pham Ngoc Thach, **BV đa khoa Nhơn Trach, Đồng Nai Chịu trách nhiệm chính: Đặng Vĩnh Hiệp Email: hiepdv@pnt.edu.vn

Ngày nhận bài: 30/10/2020

Ngày phản biên khoa hoc: 25/11/2020

Ngày duyệt bài: 16/12/2020
}

\section{Đặng Vĩnh Hiệp*, Đỗ Thị Nguyên**}

Long Thành từ từ tháng 05 năm 2017 đến tháng 12 năm 2017. Tiến hành thu thập các số liệu về lâm sàng, và các đặc điểm hình ảnh trên phim CLVT sọ não không tiêm thuốc theo mẫu bênh án có sẵn. Phân tích số liệu theo phần mềm thống kê thích hợp và đưa ra kết quả theo mục tiêu nghiên cứu. Kết quả và kết luâan: Liên quan một số yếu tố nguy cơ với loại tổn thương (nhồi máu não, xuất huyết não): Tuổi trung bình của đối tượng nhối máu não $(68,0 \pm 13,5)$ cao hơn xuất huyết não $(60,6 \pm 17,1)$ có ý nghĩa thống kê $(p<0,05)$. Tỉ lệ nhồi máu não và tỉ lệ xuất huyết não không phụ thuốc vào giới và các yếu tố nguy cơ khác như: tăng huyểt áp, đái tháo đường, bênh lý tim mạch $\left(X^{2}, p>0,05\right)$. Liên quan giữa đặc điểm lâm sàng với loại tổn thương: Xuất huyết não có tỉ lệ rối loạn vận động $(80,0 \%)$ cao hơn nhồi máu não $(41,5 \%)\left(\dot{X}^{2}, p<\right.$ 
0,01). Xuất huyết não có tỉ lệ rối loạn cảm giác $(91,4 \%)$ cao hơn nhồi máu não $(47,6 \%)\left(X^{2}, p<\right.$ $0,001)$. Xuất huyết não có tỉ lệ rối loạn ngôn ngữ $(51,4 \%)$ cao hơn nhồi máu não $(14,6 \%)\left(X^{2}, p<\right.$ $0,001)$. Giữa hai loại tổn thương tỉ lệ rối loạn trí nhớ khác biệt không có ý nghĩa thống kê.

Từ khóa: Đột quy não cấp, nhồi máu não, xuất huyết não, CLVT sọ não ...

\section{SUMMARY \\ RESEACH FOR THE RELATIONSHIP BETWEEN CLINICAL AND NON- \\ ENCHANCEMENT CT IN ACUTE STROKE}

Purpose: Evaluation the relationship of clinical presentation and NECT feartures in acute stroke. Objective and method: A prospective, crosssectional study of 120 acute stroke patient who had take for the clinical examination and NECT in Local general Hospital Long Thanh, from May 2017 to December 2017. We collected clinical data and NECT findings according base on medical records. Analysis of algorithm data base on statistical software and give results to research objectives. Results and conclusion: Relation between risk factors and lesion type (cerebral infarction, cerebral hemorrhage): Mean age of subjects with cerebral infarction $(68.0 \pm 13.5)$ was higher than cerebral hemorrhage $(60.6 \pm 17.1)$ significant differences $(p<0.05)$. The rate of cerebral infarction and cerebral hemorrhage had not relation with sex and other risk factors (hypertension, diabetes, cardiovascular disease) $(x 2, p>0.05)$. The relationship between the clinical features and brain lesion type: The rating of movement disoder in cerebral hemorrhage $(80 \%)$ was higher than its cerebral infarction $(41.5 \%)(x 2, p<0.01)$. The rating of sensory disorders in cerebral hemorrhage $(91.4 \%)$ was higher than cerebral infarction $(47.6 \%)(x 2, p$ $<0.001$ ). The rating of languege disorders in cerebral hemorrhage $(51.4 \%)$ was higher than cerebral infarction $(14.6 \%) \quad(x 2, p<0.001)$. The rating of memory disorders in both type was no significant differences.

Keyword: Acute stroke, cerebral infarction, cerebral hemorrhage, brain CT...

\section{I. ĐĂT VẤN ĐỀ}

Tai biến mạch máu não là sự xảy ra đột ngột với các thiếu sót chức năng thân kinh thường khu trú hơn là lan tỏa, tồn tại trên 24 giờ hoặc gây tử vong trong vòng 24 giờ (loại trừ nguyến nhân do chấn thương).

Tai biến mạch máu não bao gồm thiếu máu não và chảy máu não, trong đó thiếu máu não chiếm đa số. Theo báo cáo của Hội Tim mạch Hoa Kỳ có khoảng $87 \%$ đột quy não là thiếu máu não. Đây là bệnh lý thường gặp đặc biệt là các nước phát triển và là nguyên nhân thứ hai gây tử vong và thứ ba gây tàn tật trên thế giới. Trên thế giới, năm 2010, có 16,9 triệu người mới mắc, 33,0 triệu người mắc, 5,9 triệu người chết do đột quy. [1].
Chụp cắt lớp vi tính sọ não không cản quang được áp dụng rộng rãi trong đột quy não do thực hiện nhanh chóng, sự chịu đựng và độ tin cậy cao. Chụp cắt lớp vi tính cho phép loại trừ chảy máu não, có thể cho phép chẩn đoán thiếu máu não sớm, điêu này giúp ích rất nhiều cho việc chẩn đoán, điều trị tái tưới máu và theo dõi sau điều trị. Việc đi sâu nghiên cứu lâm sàng và hình ảnh CLVT là rất quan trọng, có tính thời sự và giá trị khoa học cao cho lầm sàng thân kinh, can thiệp mạch. Vì vậy chúng tôi tiến hành nghiên cứu đề tài: "Nghiên cứu mối liên quan giữa lâm sàng và hình ảnh CLVT sọ não ở bệnh nhân đột quy. não cấp".

\section{II. ĐỐI TƯƠ'NG VÀ PHƯƠNG PHÁP NGHIÊN CỨU}

2.1. Đối tượng nghiên cứu: Cõ mẫu nghiên cứu gồm 120 bệnh nhân được chẩn đoán lâm sàng là đột quỵ não và được chụp chụp CLVT sọ não không tiêm thuốc cản quang tại Bệnh viện ĐKKV Long Thành từ từ tháng 05 năm 2017 đến tháng 12 năm 2017.

2.2. Phương pháp nghiên cứu: Tiến cứu, mô tả cắt ngang.

2.3. Quy trình nghiên cứu: Thu thập các số liệu về lâm sàng, và các đặc điểm hình ảnh trên phim CLVT so não không tiêm thuốc theo mẫu bệnh án có sẵn. Phân tích số liệu theo phân mềm thống kê thích hợp và đưa ra kết quả theo mục tiêu nghiên cứu.

\section{KẾT QUẢ NGHIÊN CứU}

3.1. Đăc điểm tuổi và giới của $B N$ nghiên cứu: Với $120 \mathrm{BN}$ nghiên cứu, có nam/nữ=1.2/1. Tuổi trung bình: 65,7 \pm 14,8 (nhỏ nhất: 30 tuổi; Iớn nhất: 90 tuổi).

Bảng 3.1. Liên quan giữa tuổi và giới $(n=120)$

\begin{tabular}{|c|c|c|c|}
\hline Giới & Số TH & Tuối TB \pm ĐLC & p, T-test \\
\hline Nam & 66 & $63,3 \pm 14,0$ & \multirow{3}{*}{0,048} \\
\hline Nữ & 54 & $68,7 \pm 15,4$ & \\
\hline \multicolumn{2}{|c|}{$\begin{array}{c}\text { Giá trị khác } \\
\text { biệt }\end{array}$} & $\begin{array}{c}5,4(95 \% \text { KTC } \\
0,04-10,7)\end{array}$ & \\
\hline
\end{tabular}

Nhận xét: Tuối trung bình của đối tượng nữ cao hớn nam 5,4 tuổi (95\% KTC: 0,04 - 10,7 tuổi), sự khác biệt có ý nghĩa thống kê ( $p<0,05$, T-test).

3.2. Mối liên quan giữa một số yếu tố nguy cơ, lâm sàng với hình ảnh CLVT

Bảng 3.2. Liên quan giữa tuổi với loại tổn thương( $n=120)$

\begin{tabular}{|c|c|c|}
\hline $\begin{array}{c}\text { Loại tổn } \\
\text { thương }\end{array}$ & $\begin{array}{c}\text { Tuối TB } \pm \\
\text { ĐLC }\end{array}$ & $\begin{array}{c}\mathbf{p} \\
\text { (T-test) }\end{array}$ \\
\hline $\begin{array}{c}\text { Nhồi máu não } \\
(\mathrm{n}=82)\end{array}$ & $68,0 \pm 13,5$ & $0,013^{*}$ \\
\hline
\end{tabular}


VIETNAM MEDICAL JOURNAL N¹ - JANUARY - 2021

\begin{tabular}{|c|c|}
\hline $\begin{array}{c}\text { Xuất huyết não } \\
(\mathrm{n}=35)\end{array}$ & $60,6 \pm 17,1$ \\
\hline $\begin{array}{c}\text { Khác biệt giá trị } \\
\text { TB }\end{array}$ & $\begin{array}{c}7,4 \text { tuối } \\
(95 \% \text { KTC: } 1,6-13,3)\end{array}$ \\
\hline
\end{tabular}

Nhân xét: Tuổi trung bình của nhóm nhồi máu não cao hơn nhóm xuất huyết não 7,4 tuổi (95\% KTC: 1,6-13,3), sự khác biệt có ý nghĩa thống kê $(p<0,05)$.

Bảng 3.3. Liên quan giữa giới với loại tổn thương $(n=120)$

\begin{tabular}{|c|c|c|c|c|}
\hline \multirow{2}{*}{ Loại tổn thương } & Nam & Nữ & Cộng & \multirow{2}{*}{$\mathbf{P}\left(\mathbf{X}^{\mathbf{2}}\right)$} \\
\cline { 2 - 4 } & Số TH (\%) & Số TH (\%) & Số TH (\%) & \multirow{2}{*}{$\mathbf{0}, \mathbf{2 7}$} \\
\hline Nhồi máu não & $45(68,2)$ & $37(68,5)$ & $82(68,3)$ & \\
\hline Xuất huyết não & $18(27,3)$ & $17(31,5)$ & $35(29,2)$ & \\
\hline Kết hợp & $3(4,5)$ & $0(0,0)$ & $3(2,5)$ & \\
\hline Cộng & $\mathbf{6 6}(\mathbf{1 0 0})$ & $\mathbf{5 4 ( 1 0 0 )}$ & $\mathbf{1 2 0}(\mathbf{1 0 0})$ & \\
\hline
\end{tabular}

Nhận xét: Tỉ lệ loại tổn thương giữa nam và nữ khác biệt không có ý nghĩa thống kê $(p>0,05)$.

Bảng 3.4. Liên quan giữa huyết áp với loại tổn thương $(n=120)$

\begin{tabular}{|c|c|c|c|c|}
\hline \multirow{3}{*}{ Loại tổn thương } & \multicolumn{2}{|c|}{ Tăng huyết áp } & \multirow{2}{*}{ Cộng } & \multirow{2}{*}{$p\left(x^{2}\right)$} \\
\hline & Có & Không & & \\
\hline & Số TH (\%) & Số TH (\%) & Số TH (\%) & \multirow{5}{*}{0,69} \\
\hline Nhồi máu não & $57(66,3)$ & $25(73,5)$ & $82(68,3)$ & \\
\hline Xuất huyết não & $27(31,4)$ & $8(23,5)$ & $35(29,2)$ & \\
\hline Kết hợp & $2(2,3)$ & $1(2,9)$ & $3(2,5)$ & \\
\hline Cộng & $86(100)$ & $34(100)$ & $120(100)$ & \\
\hline
\end{tabular}

Nhận xét: Tỉ lệ loại tổn thương khác biệt giữa có và không tăng huyết áp không có ý nghĩa thống kê $(p>0,05)$.

Bảng 3.5. Liên quan giữa đái tháo đường với loại tổn thương $(n=120)$

\begin{tabular}{|c|c|c|c|c|}
\hline \multirow{2}{*}{ Loại tổn thương } & \multicolumn{2}{|c|}{ Đái tháo đường } & \multirow{2}{*}{ Cộng } & \multirow{2}{*}{$\mathbf{p}\left(\mathbf{X}^{\mathbf{2}}\right)$} \\
\cline { 2 - 3 } & Có & Không & Số TH $(\%)$ & \\
\cline { 2 - 4 } & Số TH (\%) & Số TH(\%) & $82(68,3)$ & \\
\hline Nhồi máu não & $18(75,0)$ & $64(66,7)$ & $35(29,2)$ & \multirow{2}{*}{0,57} \\
\hline Xuất huyết não & $6(25,0)$ & $29(30,2)$ & $3(2,5)$ & \\
\hline Kết hợp & $0(0,0)$ & $3(3,1)$ & $\mathbf{1 2 0}(\mathbf{1 0 0})$ & \\
\hline Cộng & $\mathbf{2 4 ( 1 0 0 )}$ & $\mathbf{9 6 ( 1 0 0 )}$ & \\
\hline
\end{tabular}

Nhận xét: Tî lệ loại tổn thương giữa có và không đái tháo đường khác biệt không có ý nghĩa thống kê $(p>0,05)$.

Bảng 3.6. Liên quan giữa bệnh tim mạch với loại tổn thương(n=120)

\begin{tabular}{|c|c|c|c|c|}
\hline \multirow{3}{*}{ Loại tổn thương } & \multicolumn{2}{|c|}{ Bệnh tim mạch } & \multirow{2}{*}{ Cộng } & \multirow[b]{2}{*}{$p\left(x^{2}\right)$} \\
\hline & Có & Không & & \\
\hline & Số TH (\%) & Số TH (\%) & Số TH (\%) & \multirow{5}{*}{0,62} \\
\hline Nhồi máu não & $26(74,3)$ & $56(65,9)$ & $82(68,3)$ & \\
\hline Xuất huyết não & $8(22,9)$ & $27(31,8)$ & $35(29,2)$ & \\
\hline Kết hợp & $1(2,9)$ & $2(2,4)$ & $3(2,5)$ & \\
\hline Cộng & $35(100)$ & $85(100)$ & $120(100)$ & \\
\hline
\end{tabular}

Nhận xét: Tỉ lệ loại tổn thương giữa có và không bệnh tim mạch khác biệt không có ý nghĩa thống kê $(p>0,05)$.

Bảng 3.7. Liên quan giữa rôi loạn vận động với loại tổn thương( $n=120)$

\begin{tabular}{|c|c|c|c|c|}
\hline \multirow{3}{*}{ Loại tổn thương } & \multicolumn{2}{|c|}{ Rối loạn vận động } & \multirow{2}{*}{ Cộng } & \multirow{2}{*}{$p\left(x^{2}\right)$} \\
\hline & Có & Không & & \\
\hline & Số TH (\%) & Số TH (\%) & Số TH (\%) & \multirow{5}{*}{0,001} \\
\hline Nhôi máu não & $34(41,5)$ & $48(58,5)$ & $82(100)$ & \\
\hline Xuất huyết não & $28(80,0)$ & $7(20,0)$ & $35(100)$ & \\
\hline Kết hợp & $2(66,7)$ & $1(33,3)$ & $3(100)$ & \\
\hline Cộng & $64(53,3)$ & $56(46,7)$ & $120(100)$ & \\
\hline
\end{tabular}

Nhận xét. Tỉ lệ rối loạn vận động ở nhóm xuất huyết não cao hơn nhóm nhồi máu não có ý nghĩa thống kê $(p<0,01)$. 
Bảng 3.8. Liên quan giữa rối loạn cảm giác với loại tổn thương( $n=120)$

\begin{tabular}{|c|c|c|c|c|}
\hline \multirow{3}{*}{ Loại tổn thương } & \multicolumn{2}{|c|}{ Rối loạn cảm giác } & \multirow{2}{*}{ Cộng } & \multirow{2}{*}{$p\left(x^{2}\right)$} \\
\hline & Có & Không & & \\
\hline & Số TH (\%) & Số TH (\%) & Số TH (\%) & \multirow{5}{*}{0,000} \\
\hline Nhồi máu não & $39(47,6)$ & $43(52,4)$ & $82(100)$ & \\
\hline Xuất huyết não & $32(91,4)$ & $3(8,6)$ & $35(100)$ & \\
\hline Kết hợp & $3(100)$ & $0(0,0)$ & $3(100)$ & \\
\hline Cộng & $74(61,7)$ & $46(38,3)$ & $120(100)$ & \\
\hline
\end{tabular}

Nhận xét: Tỉ lệ rối loạn cảm giác ở nhóm xuất huyết não cao hơn nhóm nhồi máu não có ý nghĩa thống kê $(p<0,001)$.

Bảng 3.9. Liên quan giữa rôi loạn ngôn ngữ với loại tổn thương(n=120)

\begin{tabular}{|c|c|c|c|c|}
\hline \multirow{2}{*}{ Loại tổn thương } & \multicolumn{2}{|c|}{ Rối loạn ngôn ngữ } & \multirow{2}{*}{ Cộng } & \multirow{2}{*}{$\mathbf{p}\left(\mathbf{x}^{\mathbf{2}}\right)$} \\
\cline { 2 - 3 } & Có & Không & Số TH $(\%)$ & \\
\cline { 2 - 4 } & Số TH $(\%)$ & Số TH(\%) & \multirow{2}{*}{0,000} \\
\hline Nhồi máu não & $12(14,6)$ & $70(85,4)$ & $82(100)$ & \\
\hline Xuất huyết não & $18(51,4)$ & $17(48,6)$ & $35(100)$ & \\
\hline Kết hợp & $2(66,7)$ & $1(33,3)$ & $3(100)$ & \\
\hline Cộng & $\mathbf{3 2 ( 2 6 , 7 )}$ & $\mathbf{8 8 ( 7 3 , 3 )}$ & $\mathbf{1 2 0 ( 1 0 0 )}$ & \\
\hline
\end{tabular}

Nhận xét: Tỉ lệ rối loạn ngôn ngữ ở nhóm xuất huyết não cao hơn nhóm nhồi máu não có ý nghĩa thống kê $(p<0,001)$.

Bảng 3.10. Liên quan giữa rôi loạn trí nhớ với loại tổn thương( $n=120)$

\begin{tabular}{|c|c|c|c|c|}
\hline \multirow{3}{*}{ Loại tổn thương } & \multicolumn{2}{|c|}{ Rối loạn trí nhớ } & \multirow{2}{*}{ Cộng } & \multirow{2}{*}{$p\left(x^{2}\right)$} \\
\hline & Có & Không & & \\
\hline & Số TH (\%) & Số TH (\%) & Số TH (\%) & \multirow{5}{*}{0,45} \\
\hline Nhồi máu não & $15(18,3)$ & $67(81,7)$ & $82(100)$ & \\
\hline Xuất huyết não & $9(25,7)$ & $26(74,3)$ & $35(100)$ & \\
\hline Kết hợp & $0(0,0)$ & $3(100)$ & $3(100)$ & \\
\hline Cộng & $24(20,0)$ & $96(80,0)$ & $120(100)$ & \\
\hline
\end{tabular}

Nhận xét: Tỉ lệ rối loạn trí nhớ ở nhóm xuất huyết não cao hơn nhóm nhồi máu não (25,7\% so với 18,3\%), nhưng không có ý nghĩa thống kê $(p>0,05)$.

\section{BÀN LUẬN}

4.1. Đặc điểm tuổi và giới của $B N$ nghiên cứu: Số đối tượng nghiên cứu 120, tỉ lệ nam chiếm ưu thế $(55,0 \%) ;$ nam/nữ $=1,2 / 1$. Năm 2016, Đỗ Văn Việt và cs. nghiên cứu đặc điểm lâm sàng, hình ảnh cắt lớp vi tính sọ não ở 946 bệnh nhân nhồi máu não, điều trị tại Khoa Đột quy, Bệnh viện Quân y 103 từ 01/01/2015 đển 30/6/2016, ghi nhận tỉ lệ nam/nữ = 1,71/1. Tuổi trung bình của đối tượng trong nghiên cứu của chúng tôi tương đương với nghiên cứu của Đỗ Văn Việt và cs: 67,76 $\pm 12,35$ [2].

4.2. Mối liên quan giữa một số yếu tố nguy cơ, lâm sàng với hình ảnh CLVT: Tuổi, giới và CLVT: Trong nghiên cứu này, chúng tôi thấy tuổi trung bình của nhóm nhồi máu não $(68,0 \pm 13,5)$ cao hơn nhóm xuất huyết não $(60,6 \pm 17,1)$ là 7,4 tuổi (95\% KTC: $1,6-13,3)$, sự khác biệt có ý nghĩa thống kê $(p<0,05)$ (bảng 3.16). Kết quả chúng tôi khác với tác giả Nguyễn Đình Cường và CS tại Bệnh viện C Đà Nẵng, nghiên cứu trên 98 BN đột quỵ từ 5/2014 đến $5 / 2015$. Kết quả ghi nhận tuổi trung bình của
NMN là $69,33 \pm 13,11$, XHN là $73,13 \pm 11,48$, khác biệt không có ý nghĩa thống kê về tuổi giữa thể XHN và thể NMN $(p>0,05)$ [3]. Điều này có thể giải thích rằng, XHN độ tuổi thường trẻ hơn do có nhiêu trường hợp nguyên nhân là dị dạng mạch não sẽ gây tai biến não sớm hơn nhóm nhồi máu não. Tỉ lệ loại tổn thương giữa nam và nữ khác biệt không có ý nghĩa thống kê ( $p>0,05)$ (Bảng 3.2, 3.3).

Liên quan giữa một số yếu tố nguy cớ và thể tổn thương. Các yếu tố nguy cơ như THA, ĐTĐ, bệnh lý tim mạch liên quan trực tiếp đến tý lệ đột quỵ não, tuy nhiên không có sự khác biệt về thể tổn thương giữa nhóm nhồi máu và nhóm xuất huyết não - Bảng 3.4, 3.5, 3.6. Đỗ Văn Việt và cs ghi nhận: Yếu tố nguy cơ (YTNC) hay gặp nhất là THA (72,93\%), đái tháo đường (ĐTĐ) $(21,35 \%)$, rung nhĩ $(11,86 \%)$, chưa tìm thây YTNC (10,14\%) [2]. Lê Quang Minh nhận xét đặc điểm lâm sàng, cận lâm sàng 148 bệnh nhân XHN điều trị tại Bệnh viện Đa khoa tỉnh Hà Nam từ 01/2014 đến 01/2016. Kết quả: Các YTNC thường gặp là THA 89,2\%, rối loạn chuyển hóa 
lipit 47,3\%; ĐTÐ 22,3\%; nghiện rượu 18,9\% và ăn mặn 36,5\%. Tổng hợp YTNC trên $1 \mathrm{BN}, 1$ YTNC 12,2\%; 2 YTNC 59,2\%; 3 YTNC 24,3\%, > 3 YTNC 4,0\%[4]. Năm 2017, Nguyễn Minh Hiện và cs. nghiên cứu đặc điểm lâm sàng, cận lâm sàng và một số YTNC liên quan đến NMN ở BN dưới 50 tuổi. Nghiên cứu tiến cứu, mô tả cắt ngang có đối chứng 125 BN NMN giai đoạn cấp (nhóm nghiên cứu gồm $59 \mathrm{BN}$ tuổi từ 20-50; nhóm chứng 66 BN tuổi từ 50-93). Kết quả: Lạm dụng rượu bia cao hơn ở nhóm trên 50 tuổi 2,68 lần; nghiện hút thuốc lá cao hơn ở nhóm trên 50 tuổi 7,57 lần; ĐTĐ thấp hơn ở nhóm trên 50 tuổi 2,99 lần, rối loạn chuyển hóa lipit máu thấp hơn ở nhóm trên 50 tuổi 2,17 lần [5].

Liên quan giữa một số đăc điểm lâm sàng với hình ảnh cắt lớp vi tính. Chúng tôi khảo sát liên quan một sốt đặc điểm lâm sàng với thể tổn thương trên hình ảnh chụp CLVT không cản quang ghi nhận: NMN có rối loạn vận động $41,5 \%$ thấp hơn so với XHN $(80,0 \%)$ ( $p<$ $0,01)$. Khảo sát về rối loạn cảm giác $\mathrm{NMN}$ là $47,6 \%$ thấp hơn XHN 91,4\% ( $p<0,001)$. Rối loạn ngôn ngữ: NMN 14,6\%; XHN 51,4\%, khác biệt có ý nghĩa thống kê $(p<0,001)$.Chúng tôi khảo sát liên quan giữa rối loạn trí nhớ với loại tổn thương, kết quả cho thây tî lệ rối loạn trí nhớ ở nhóm xuất huyết não cao hơn nhóm nhồi máu não $(25,7 \%$ so với $18,3 \%)$, nhưng không có ý nghĩa thống kê $(p>0,05)$ (Bảng 3.7, 3.8, 3.9, 3.10). Có một số sự khác biệt về lâm sàng như trên là do trong XHN, tổn thương thường gây choán chỗ và tăng áp lực nội sọ nên không gây ra thương tổn gần như vĩnh viễn, còn nhồi máu não sẽ có vùng "tranh tối - tranh sàng" nằm giữa nhu mô não lành và nhu mô não hoại tử, bên cạnh đó có hệ thống mạch máu bàng hể nên các tổn thương có khả năng hồi phục tốt hơn.

Năm 2017, Lê Quang Minh nhận xét đặc điểm lâm sàng, cận lâm sàng 148 bệnh nhẩn XHN điều trị tại Bệnh viện Đa khoa tỉnh Hà Nam từ 01/2014 đến 01/2016. Kết quả: tuổi trung bình $68,16 \pm 13,2$; tỉ lệ nam/nữ 1,63. Thời điểm trong ngày thường gặp 6-9 giờ (20,9\%). Các YTNC thường găp là THA $89,2 \%$, rối loạn chuyển hóa lipit 47,3\%; hút thuốc lá 36,5\%; ĐTĐ 22,3\%; nghiện rượu $18,9 \%$ và ăn mặn $36,5 \%$. Tổng hợp YTNC trên 1 BN, 1 YTNC 12,2\%; 2 YTNC 59,2\%; 3 YTNC 24,3\%, > 3 YTNC 4,0\%. Tính chất khởi phát đột ngột $52,7 \%$; cấp tính $35,1 \%$, từ từ $12,2 \%$. Các triệu chứng thường gặp khi khởi phát: đau đầu $86,5 \%$; nôn, buồn nôn $75,0 \%$; liệt nửa người $82,4 \%$; rối loạn ý thức $79,0 \%$; rối loạn ngôn ngữ 46,6\%; rối loạn cảm giác 42,6\%; rối loạn cơ vòng $21,6 \%$ và co giật $10,8 \%$ [4]. Đố Đức Thuần và cs. nghiên cứu lâm sàng, hình ảnh CT sọ não và kết quả điều trị rTPA đường tĩnh mạch ở 53 bệnh nhân đột quy NMN có kèm rung nhĩ tại Bệnh viện Quân y 103, từ 1/2013 đến 3/2017. Kết quả: tuổi trung bình $65,19 \pm 13,55$, tỉ lệ BN nam 41,51\%; các YTNC: bệnh van tim $32,07 \%$, THA $28,3 \%$. Điểm trung bình NIHSS $17,25 \pm 4,45$; liệt tay nặng hơn chân $79,24 \%$ [6]. Đỗ Đào Vũ và̀ cs. so sánh đặc điểm động lực niệu ở 58 BN đột quy. NMN và $26 \mathrm{BN}$ XHN tại Bệnh viện Bạch Mai năm 2016-2017. Kết quả: Nhóm XHN có tỉ lệ cường co bóp bàng quang cao hơn nhóm NMN ( $p<0,05 ; x^{2}$ test). Thể tích tối đa và thể tích tồn lưu bàng quang ở nhóm XHN cao hơn NMN có ý nghĩa thống kê $(p<0,05$; Mann Withney test) [7].

\section{KẾT LUÂ̂N}

Đánh giá mối tương quan giữa lâm sàng với hình ảnh CLVT là cần thiết trong việc việc chẩn đoán sớm và điều trị kịp thời, là yêu cầu tiên quyết trong đột quỵ não vì "thời gian là não".

\section{TÀI LIẸU THAM KHẢO}

1. Shen J., Li Y., et al (2017), "Comparative accuracy of $C T$ perfusion in diagnosing acute ischemic stroke: A systematic review of 27 trials", PLOS ONE, 12(5), e0176622, 1-17.

2. Đố Văn Việt, Nguyễn Đăng Hải và cs. (2016), "Đặc điểm đột quỵ. nhồi máu não tại Bệnh viện Quân y 103", Tạp chí Y - Dược học quân sự, số chuyên đề đột quy., 56-62.

3. Nguyễn Đình Cường, Nguyễn Đình Toàn (2016), "Nghiên cứu nồng độ hs-CRP, fibrinogen, tốc độ máu lắng ở bệnh nhân tai biến mạch máu não giai đoan cấp", Tạp chí Y - Dược học quân sự, số chuyên đề đột quy, 43-49.

4. Lê Quang Minh (2017), "Đặc điểm lâm sàng, cận lâm sàng ở bệnh nhân chảy máu não điêu trị tại Bệnh viện đa khoa tỉnh Hà Nam", Tạp chí Y - Dược hơc quân sứ, 4, 107-113.

5. Nguyễn Minh Hiện, Nguyễn Trọng Tuyên (2017), "Nghiên cứu đặc điểm lâm sàng, cận lâm sàng và một số yếu tố liê̂n quan đến nhồi máu não ở bệnh nhần dưới 50 tuổi", Tạp chí Y - Dược học quận sự, 4, 101-106.

6. Đỗ Đức Thuân, Phạm Đình Đài, Nguyễn Thanh Xuân (2017), "Nghiên cứu lâm sàng, hình ảnh CT sọ não và kết quả điều trị rTPA đường tĩnh mach ở bệnh nhân đôt quy nhồi máu não có kèm rung nhî", Tap chí Y - Dược học quân sự, 8, 82-86.

7. Vu D.D., Xuan Ng.Th. (2017), "Comparison of urodynamic characteristics in cerebral hemorrhage and ischemic stroke patients at Bach Mai Hospital in 2016-2017", Journal of Military PharmacoMedicine, 7, 127-131. 